\title{
Land value taxation in Germany: theoretical and historical issues
}

Citation for published version (APA):

Backhaus, J. G. (1997). Land value taxation in Germany: theoretical and historical issues. METEOR, Maastricht University School of Business and Economics. METEOR Research Memorandum No. 033 https://doi.org/10.26481/umamet.1997033

Document status and date:

Published: 01/01/1997

DOI:

10.26481/umamet.1997033

Document Version:

Publisher's PDF, also known as Version of record

\section{Please check the document version of this publication:}

- A submitted manuscript is the version of the article upon submission and before peer-review. There can be important differences between the submitted version and the official published version of record.

People interested in the research are advised to contact the author for the final version of the publication, or visit the DOI to the publisher's website.

- The final author version and the galley proof are versions of the publication after peer review.

- The final published version features the final layout of the paper including the volume, issue and page numbers.

Link to publication

\footnotetext{
General rights rights.

- You may freely distribute the URL identifying the publication in the public portal. please follow below link for the End User Agreement:

www.umlib.nl/taverne-license

Take down policy

If you believe that this document breaches copyright please contact us at:

repository@maastrichtuniversity.nl

providing details and we will investigate your claim.
}

Copyright and moral rights for the publications made accessible in the public portal are retained by the authors and/or other copyright owners and it is a condition of accessing publications that users recognise and abide by the legal requirements associated with these

- Users may download and print one copy of any publication from the public portal for the purpose of private study or research.

- You may not further distribute the material or use it for any profit-making activity or commercial gain

If the publication is distributed under the terms of Article $25 \mathrm{fa}$ of the Dutch Copyright Act, indicated by the "Taverne" license above, 


\section{Land Value Taxation in Germany: Theoretical and Historical Issues}

Essay prepared for a Compendium on Land Value Taxation Around the World to be published on the occasion of the 100th anniversary of the death of Henry George. ${ }^{1}$

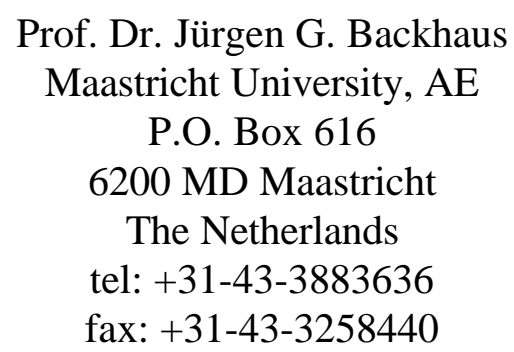

email: f.schijlen@algec.unimaas.nl

1 Thanks to Reginald Hansen for extensive suggestions and help with this article. 


\begin{abstract}
Land value taxation in Germany has a long history pre-dating and post-dating Henry George's own influence. Some of the ideas Henry George stood for had already taken root in German practice before him, and when his books began to appear almost simultaneously with their American editions in Germany, a German intellectual and political movement began to emerge rallying around the issue of land reform. In this essay, first the intellectual roots of Georgist ideas in German literature are being retraced. Secondly, the practice of land value taxation, or more precisely land added value taxation is being described. The core of Henry George's ideas, however, is embodied not in the legislation on land added value taxation, but rather appended to the income tax code. This is the topic of the third section. Since the interplay between German income tax legislation and investment decisions is hard to grasp for the uninitiated from a purely theoretical discussion, an example is being analyzed in the fourth section in order to illustrate how this "Georgist" system of taxation operates in practice.
\end{abstract}

J.E.L. code: B19, B3, H24, H25, H29 and 35

Key words: Land added value taxation, land reform, reconstruction in Germany 


\section{Introduction}

Land value taxation in Germany has a very long and multifaceted history. This history extends well into several centuries before Henry George's (1839-1897) writings appeared. His work was, however, well received in Germany, and he became part of a larger intellectual movement, which also gathered political momentum. This political momentum translated into imperial and municipal legislation. The land reform movement, of which Henry George's ideas became an integral part, had, as does Henry George's own work, the dual focus of on the one hand trying to overcome urban squalor, but on the other hand more generally present a developmental strategy for optimal resource use. This aspect, in Germany, became particularly pressing after the two catastrophies following military defeat Germany suffered in 1918 and 1945. The task of reconstruction required specific tools of taxation. Similarly, re-unification of Germany in 1990 presented the country with a massive challenge of reconstructing the east after the collapse of the German Democratic Republic which had, in particular during its last years, practiced massive dis-investment.

This historical and intellectual situation in Germany painted here with just a few broad brushes suggests the following structure of this essay. In the first section, the intellectual roots of Georgist ideas in German literature are being sketched. Secondly, the specific issue of land value taxation, and in particular land added value taxation is explored in some detail. Thirdly, however, the core of Georgist tax legislation lies not in the taxation of land but rather in the income tax code as it interconnects with business investment decisions, in particular investment in real estate. This issue has to my knowledge been overlooked in Georgist literature so far. Section three is devoted to explaining the system theoretically, and section four gives an example illustrating how the system operates in practice. 
Taking the land rent into account is by no means a modern concept, it has played a significant role in European economic history, at least from the times of the Middle-ages, and including the history of economic ideas. For example, farm sizes and levies depended on the fertility of land, not the actual product, during feudal times in the whole Roman Empire (established in the year 800). This indicates that the land rent, and not the income from land use was the determining factor. The reason for this arrangement, it should be kept in mind, was not equity in taxation. Equity in taxation would have called for basing levies on ability to pay, such as real yields, number of people to be maintained or other such considerations. Yet, household size became an endogenous variable, as marriage licenses were only given upon proof of sufficient means of subsistence and a need for the labour of the likely offspring. Taking the land rent into consideration was a matter of efficiency, since those farmers who did not produce sufficient yields in order to pay the tax were driven off their farms. In this sense, Schumpeter is perfectly justified in calling the gist of Henry George's proposal "obvious wisdom". ${ }^{2}$ When Henry George's Progress and Poverty appeared in German, in $1880^{3}$ it met with wide spread approval

2 Joseph Alois Schumpeter, History of Economic Analysis, New York: Oxford University Press, 1954, p. 865.

3 Henry George, Fortschritt und Armut, translated by C.D.F. Gütschow, Berlin: Staude, 1880 (with a preface by Henry George himself in German, dated San Francisco, August 10,1881); there is another even more beautifully produced edition based on a different translation: Henry George, Fortschritt und Armut, translated by F. Dobbert, Halle: Hendel, no year [1891], in a series called Complete Domestic and International Library with each volume selling for 25 pfennig. 
and appeal ${ }^{4}$. It met with immediate approval, but at the same time it was pointed out that the proposal itself lacked originality but not force of conviction. It is generally argued that William Ogilvie first made the proposal, then James Mill and John Stuart Mill followed suit, but before George also Friedrich List had in no uncertain terms argued the same point in 1845. This source is well worth mentioning, because it emphasizes again the efficiency aspect of George's proposal over the equity aspect, which is dominant in the writings of Mill but also later in Adolph Wagner's treatment. Friedrich List was writing an expert opinion about the economic development of the kingdom of Hungary in $1845 .{ }^{5}$ Specifically he said: "If the Hungarian state increases the land rent many fold by undertaking improvements in water and transport infrastructure, the increase often being twenty fold, then the state should at least take half of the added value by means of a tax advance upon the occasion of the transfer of such real estate. ${ }^{6}$ This highly specific and sophisticated tax instrument, which shows Friedrich List as a

4 See for instance the long review article by Gustav von Schmoller himself, see Gustav Schmoller, "Henry George", in Gustav Schmoller, Zur Literaturgeschichte der Staatsund Sozialwissenschaften, Leipzig: Duncker \& Humblot, 1888, the original is dated 1882 and is a review of the Gütschow translation of 1881.

$5 \quad$ Friedrich List, Gutachten über die wirtschaftliche Reform des Königsreichs Ungarn $\underline{1845}$.

6 The original German text reads: "Erhöht der ungarische Staat durch Wasser- und Verkehrsanlagen vielfach die Bodenrente auf das zwanzigfache, so soll - natürlich bei Gelegenheit künftige Verkäufe - der Staat mindestens die Hälfte der Wertsteigerung 
crafty expert in public finance, we shall meet again, two generations later, and implemented not in Hungary but in China.

an Steuer vorwegnehmen." 
In modern legislative history, Napoleon Bonaparte I seems to have pioneered George's idea of taxing the land rent through the so-called swamp decree of September 16, 1807, which also allowed to tax half of the increase in value of land due to public measures such as draining of wet lands, irrigation of dry lands, building of roads and establishing public places etc. ${ }^{7}$

Surprising in this early history of Georgian thought is, however, one aspect; all the authors surveyed so far did not subsribe to George's notion of constraining the state to only one form of tax revenu i.e. the $100 \%$ tax on the ground rent. When this aspect was discussed at all, it was typically dismissed as impractical or otherwise insignificant or outright in contradiction with received tax theory. ${ }^{8}$

$7 \quad$ Wilhelm Gerloff, "Die Wert zu Wachssteuer in Literatur und Gesetzgebung", Schmollers Jahrbuch für Gesetzgebung, Verwaltung und Volkswirtschaft im deutschen Reiche, 37, 1913, pp. 1485-1497.

8 This fairly extensive literature has been ably surveyed. See Fritz Stier-Somlo, "Grundsätzliches und Tatsächliches zu Wertzuwachssteuer", Jahrbücher für Nationalökonomie und Statistik, 1909, p. 1. And the article by Gerloff, cited in the previous footnote. 
Finally, another aspect needs to be addressed which characterizes not only the German literature here surveyed, but with a very few exeptions also the American literature on Henry George's contribution. ${ }^{9}$ The land rent which serves as the tax base for Henry George's $100 \%$ tax is defined over a very specific concept of land which is not identical to either soil or the surface of the earth. Yet, the entire litarature to which George is seen to have made a contribution uses a narrow concept of land (Boden) and argues for land reform (Bodenreform). Let us first look at how George defines his crucial concept of land himself.

In order to document this important definition, let us take a look at the precise way in which

9 Jürgen Backhaus and J. J. Krabbe, "Henry George's Contribution to Modern Environmental Policy: Part One, Theoretical Postulates, "American Journal of Economics and Sociology, Vol. 50 (4), 1991 (pp. 485-501).

Jürgen Backhaus, J. J. Krabbe, "Henry George's Contribution to Modern Environ-

mental

Policy:

Part

Two, An

Applicat ion to

Industria

1 Siting",

The

America

$\underline{\mathrm{n}}$

Journal

of

Economi

cs and

Sociolog

y, Vol.

51 ,

January

1992,

No. 1

(pp.

115-

127). 
George puts it forth: "Land, labour and capital are the three factors of production. If we remember that capital is thus a term used in contradistinction to land and labour, we at once see that nothing properly included under either one of these terms can be properly classed as capital. The term land necessarily includes, not merely the surface of the earth as distinguished from the water and the air, but the whole material universe outside of men himself, for it is only by having access to land, from which his very body is drawn, that men can come in contact with or use nature. The term land embraces, in short, all natural materials, forces and opportunities, and therefore, nothing that is freely supplied by nature can be properly classed as capital. A fertile field, a rich vein of ore, a falling stream which supplies power, may give to the possessor advantages equivalent to the possession of capital, but to class such things as capital would be to put an end to the distinction between land and capital, and, as far as they relate to each other, to render the two terms meaningless. The term labour, in like manner, includes all human exertion, and hence human powers whether natural or acquired can never properly be classed as capital." (George, 1881: 38-39)

The reduction of Henry George's residual category of land which includes all natural resources to land in the colloquial sense of the word as far as the German literature is concerned is not due to any defect in the translations. Both Gütschow and Dobbert translated the crucial part of chapter 2 in book I correctly ${ }^{10}$, hence other reasons must be responsible for this partial reception of Henry George's theory. By reducing its applications to just land in the sense of the surface of the earth, as the land reform movement did in Germany, it largely curtailed the impact of George's message.

10 Oddly in both editions, the quote can be found on page 31. 
Whereas in the Anglo-Saxon world, George's message was taken up on the one hand by the land reform movement, John Stuart Mill after all in 1870 had himself founded the Land Tenure Reform Association, and on the other hand by the single tax movement, in Germany Henry George's message is translated into the demand for a set of specific taxes on land added value. Already in the seventies, Adolph Wagner had defended taxing the added value of land during the meetings of the Verein für Socialpolitik, a demand he later would integrate into his public finance text book which appeared in many updated editions. Later, Flürschein propagated the same ideas ${ }^{11}$, and after the publication of Henry George's Progress and Poverty, Damaschke ${ }^{12}$, a former school teacher ${ }^{13}$, propagated the idea of land added value taxation specifically and land reform more generally with great popular success. Only after the introduction of a successful scheme of land value taxation in the German protectorate of Kiau Tchau in China, the idea took hold in the German mother country. At the end of 1910, not fewer than 652

11 Michael Flürschein, (born 1844) was the manager of Iron Works in Gaggenau and produced several pamphlets (Auf Friedlichem Wege, Der Einzige Rettungsweg, Deutschland in hundert Jahren), and a monthly paper called Deutsches Land, all arguing for land reform. This led to the constitution in 1888 of the Deutscher Bund für Bodenbesitzreform. Flürschein also tried an experiment in the Mexican state of Sinaloa, which failed. See for details, Adolph Damaschke, Geschichte der Nationalökonomie, Jena: Fischer, 1909 (3), pp. 392-393.

Adolph Damaschke was born in Berlin in 1865 and died there in 1935. The son of a carpenter who became a teacher working in the workers' districts of rapidly industrializing Berlin, he came under the influence of Henry George and tried to improve the lot of the working class through taxing the land rent. His many books include Die Aufgaben der Gemeindepolitik (The Task of Municipal Policy), Die Bodenreform (Landreform), Bodenreform in der Bibel (1906), Die Heimstättenbewegung (Saving for Private Housing)(1920), and Aus meinem Leben (My Life)(two volumes 1924/5), Bodenreform und Landwirtschaft (Land Reform and Agriculture)(1932) and Ein Kampf um Sozialismus und Nation (A Struggle for Socialism and the Nation)(1935). He held three (honorary?) doctorates, in divinity, law and medicine. 
municipalities and counties in the German Reich had adopted a land added value tax. The first German city to introduce such a specific tax was Frankfurt on the Main in 1894 without success, but a repeated effort in 1904 met with success. The Reich similarly instituted a land added value tax passed on the 15th of February 1911 and replacing specific state taxes of, for, instance Hamburg, Lübeck, Lippe, and Hesse. This act was complicated as the municipalities and counties had to participate in the revenue according to different rules, and it turned out the tax revenue for the Reich was so insignificant that only two years later, in 1913, on the third of July the constituting states of the Reich and the municipalities and counties received their taxing authority back. The Reich then proceeded to tax wealth, and the act, which remained on the books, became meaningless after the hyper inflation of 1923.

An interesting feature of tax avoidance appeared along with the rise in municipal land added value taxes. Property holding corporations in the form of joint stock corporations and limited liability corporations began to form which had as their assets land holdings assessed in their balance sheets at the expected values after development. On the basis of these balance sheets, stock was issued and thereby the capital raised for the planned development. In 1907, 174 such corporations existed in Berlin alone. This form allows for an almost complete sheltering of the land added value from taxation. 
Although the successful tax legislation in the German protectorate of Kiau Tchau set forth the spate of municipal and county land added value tax introductions in the first decade of this century in Germany, the political background of the Kiau Tchau case is altogether different and not even comparable to the standard municipal tax. As the consequence of a treaty between the German Empire and the Chinese Empire of March 6, 1898, ratified by the German Emperor on April 27, 1898, Germany took possession of the harbour of Tsingtau and the area called Kiau $\mathrm{Tchau}^{14}$ in the north of China in order to develop this natural harbour for industry, commerce and coal mining. ${ }^{15}$ Coal had been found a little further inward, a railroad line was soon to be established, allowing the transport of coal to the harbour and then on to world markets. The treaty called for the protectorate to be returned to China after successful economic development for which a duration of 99 years had been agreed on. ${ }^{16}$ Since the land to be

14 The best account can be found in W. Schrameier, Aus Kiau Tchau's Verwaltung. Die Land-, Steuer-, und Zollpolitik des Kiau Tchau Gebietes, Jena: Fischer, 1914. The author is there described as privy councillor in the Impirial Navy, formerly Imperial Commissioner of the Kiau Tchau protectorate and holding a doctorate (probably in law).

15 Wilhelm Schrameier was born in 1859 in Essen and died .... He studied divinity, philology and the law and received his doctorate in philosophy at the University of Leipzig in 1891 with a dissertation on the fatalism of the Arabs before Islam. He spent lengthy sejourns in England and France and became an apprentice interpretor at printace in the German Ambassy in Peking in 1885. Then he became an interpretor in the counsulates in Tientsin Kanton Shanghai and then the administrator of the counsulate in Hong Kong, Tchie Fu and Kanton. In 1897 he was charged with dealing with all the non-maritime affairs in the colony of Kiau Tchau, was charged with the position of civil commissioner until 1900 and became the commissioner for Chinese Affairs thereon. In this capacity, he was involved with all the economic affairs of the colony, "most of the economic institutions of which were adopted at his instigation". (Deutsches Zeitgenossenlexikon. Biographisches Handbuch deutscher Männer und Frauen der Gegenwart. Leipzig, 1905, pp. 1307-1308. He held the title of private counciller in the impirial admiralty and (ultimately) commissioned civil governor of Tsing Tao.

16 The terms of this treaty suggested by the Germans to the Chinese government, were soon thereafter reflected in the re-negotiated treaty between the British crown and the 
developed had been leased and not bought, it made sense from the start to distinguish between the improvements to be made and the land itself. Hence, the Georgian distinction between the land rent and the improvements had a natural counterpart in this particular legal arrangement. The implementation rule then was simple and echoes the one suggested by Friedrich List in 1845. 33 and a third percent of the resale value of any piece of property had to be paid to the government upon sale of the property, from which some documented value of improvements could be deducted plus six percent of the total sales price. In addition, every twenty five years one third of the land value increase had to be paid as well. These levies were not handled as taxes, but rather held by the government as mortgages secured by the land title. Now we can realize how this system operates as a developmental strategy. From the very start, the developmental authority, in this case the governor at Tsingtau, holds mortgages the value of which depends on the success of the developmental strategy. The mortgages, in turn, can be used as collateral for incurring credit, for instance in order to secure bonds. Hence, the funds for the developmental strategy are immediately available upon the start of the developmental activity, that is when the plan has been finalized and buyers have become interested in the land to be covered by the plan. ${ }^{17}$

\section{II.}

Chinese empire.

17 See for further details, Karl Bräuer, "Wertzuwachssteuer (Grundsstücksgewinnsteuer)", Handwörterbuch der Staatswissenschaften, Vol. 8, Jena: Gustav Fischer, 1928 (4), pp. 117-142. 
In Germany, the system of land taxation in general, apart from the issue of land value taxation or more specifically land added value taxation in particular, or more particularly a system of taxation which distinguishes between the land rent and the improvements, that system of land taxation remained extremely variagated until 1936. Even after the Reich had effectively abandoned its own land taxation in 1913 and assigned the revenue to the municipalities and counties, different constituting states of the Reich still practiced largely different systems, and municipal autonomy including autonomy of taxation had not been carried through in the strong form in which it had existed since the Stein Hardenberg reforms in Prussia. A common characteristic of land taxation, however, remained in Germany, and that was its independance from actual realized income or profit from the land. Ever since the medieval form of the land tax, the "Bede", efforts were made to establish set charges for each piece of land in view of its ability to produce income, a clear approximation of the land rent. In this very general and somewhat tenuous sense, German land taxation has always been a taxation of the land rent and not the improvements. In 1936, the Prussian Minister of Finance, Johannes Popitz, also Professor of Public Finance at the University of Berlin who was later to perish due to his involvement with the coup attempt of July 20, 1944, succeeded in carrying out a real estate tax reform for the entire (now centralized) Reich, assigning the tax revenue to the municipalities and counties, the tax legislation however, to the central authority as far as framework legislation was concerned, to the local authority as far as the tax rates were concerned. This is still the system as we have it today in the Federal Republic of Germany. More specifically, real estate taxation in Germany is subject to competitive legislation, which means that either the federal government or one of the sixteen constituant states can legislate, but the legislation of the federal government will prevail if both have legislated. The federal govern- 
ment has legislated the real estate tax law (Grundsteuergesetz), the assessment act (Bewertungssgesetz), the personal income tax code (Einkommenssteuergesetz), and the wealth tax act (Vermögenssteuergesetz). All these are in different ways relevant for real estate taxation, as are several other acts, such as those relating to succession duties etc. The purpose of this legislation is to establish a general framework under which, according to the same basic principles and rules, real estate taxation can take place as set forth by the different municipalities, where the real estate is located and to which the tax accrues. The value of the real estate is, principally, the unitary value established through the procedure set forth in the assessment act. This unitary value (Einheitswert), a set number in mark terms, is relevant for all manner of taxation, not only real estate taxation. The unitary value of real estate, for instance, is also relevant for corporate accounting. The unitary value is not a market value. The market value has to be used as a fair market value (gemeiner Wert) in case a unitary value has not been established. And third, there is the partial value (Teilwert) in case a particular piece of property is used by different economic entities conceivably for different purposes.

Real estate is generally classified into three different categories, which then result in two different tax categories. Real estate can conceivably be used for either agriculture or forestry (tax category A) or as private property (in household use) either with or without improvements, where the improvements are simply thought to be constructions, or else third as property for business use. This can be for commerce, production or some other legitimate business. These latter two categories of either household or business related real estate fall under the tax category B. The state legislatures can but need not legislate the relationship of tax revenues from tax categories A and B for the particular municipalities or counties. Here ends their legislative function. At this point, the municipalities and counties enter, and they, 
using the set of instruments so far described, set the tax rates (Hebesätze) for their particular tracts of real estate within their jurisdiction. Hence, since the local communities have to create the circumstances under which successful farming, forestry and commerce and business can take place, and they therefore largely determine the size of the land rent, they are also able to tax this land rent that they create to the extent that they actually create one.

Currently, the yield of the property tax is about 1.7 percent of the total tax revenues or in 1996 14.3 billion marks.

The fact that the German land tax yields only (?) some 1.7 percent of the heavy tax burden of 800 billion German marks resting on the German people (i.e. 100.000 DM per head) and her economy should not invite us to think it to be of little significance. First, one has to look at the tax and its context. Specifically, is its excess burden higher or lower than that of its closest competitors? The German property tax hovers at fairly steadily at 1.6 to 1.7 percent of the total tax revenue. The change measures above all tax accounting rule changes that needed to be flexibly accommodated. This seems to have been possible without great difficulty, i.e. the tax resistance seems to be fairly low indicating a low excess burden.

As far as context is concerned, a particular tax can almost always be avoided by paying another less burdensome tax through re-arranging business activities. This is where the German property tax together with the income tax, which in terms of yield ranks way below the property tax, assumes its particular importance. In terms of yield, the property tax ranks number nine, the income tax number fourteen. If, alternatively, income is not invested in such property as land but rather consumed, a fifteen percent value added tax needs to be paid. The value added tax ranks second among all taxes according to yield, generating more than 237 billion annually. 
A surprising feature of German tax revenues is that the income tax ranks so low. However the wage tax ranks first, generating more than 251 billion annually. In the beginning years of the Federal Republic of Germany, the income tax clearly ranked before the wage tax in yield. The enormous boost in wages and salaries made possible through investments specially treated under the tax code, of the employed work force has led to this reversal, which, of course, implies that the three most fertile taxes, the wage taxes, the value added tax and the gasoline tax which yields more than 68 billion annually are essentially borne by private households. This comes close to the ideal of a consumption tax propagated widely in the United States today.

Also by implication and in consideration of what is being explained in section IV below, the income tax has to be seen mostly in terms of the investments it generates in avoiding it. The tax is less important in terms of the revenue side of the state budget than it is in terms of the expenditure side. It reduces expenditures that otherwise would have to be made in pursuit of specific public policy perspectives, such as in the area of housing. Take this example: as one of the measures of disaster relief, on July 311997 offered tax deductions for the re-construction in the affected Oder-Bruch region.

Still, the revenues available to the municipalities and counties are by no means unimportant. Together with the land tax, there is also the corporate tax generating almost 46 billion annual1y. Municipalities and counties use these taxes, which they can tailor to the specific needs of businesses, in competing for corporate investments and influencing decisions on corporating siting. 
As the case of the recent investment by Daimler in Alabama shows, the philosophy behind this use of taxation for economic development can be exported into other jurisdictions outside Germany. ${ }^{18}$

18 The investment in Vance, Alabama, had been encouraged, if not made possible, by extensive tax concessions which are not tax expenditures, since the deductions of corporate income taxes become only relevant once the investment bears fruit. Substantial increases in local and state sales taxes and wage taxes next to the social security taxes, all due to the substantial employment effect, also need to be considered when looking at the concessions with respect to the conditions of real estate sales, etc. 
In conjuction with the local corporate tax (Gewerbesteuer), these two tax instruments in the hands of the municipalities and counties, i.e. the land value tax and the corporate tax, provide for a system of fiscal federalism that invites the municipalities and counties to compete for the business of their choice, for which they then through their active governing can create the conditions under which that business may prosper. ${ }^{19}$

III.

During this century, Germany has suffered two crushing military defeats. The first one led to the Treaty of Versailles, the economic consequences of which had been pre-saged by John Maynard Keynes. ${ }^{20}$ This peace set unlimited indemnities for several generations to come, i.e. a tax of unlimited size that the Reich had to pay to the victorious powers. The policy of the Reich was that any tax payer would adopt: seeking a compromise between compliance and avoidance. This led to several highly idiosynchratic economic policy features that still characterize German economic policy. More specifically, the Reich on the one hand had to secure the raw materials in order to not only feed the population, but also allow industrial production to generate enough exportables in order to pay the indemnities. On the other hand, the same policies had to somehow be successful in proving German's inability to pay. Most specifically, Germany had not only lost its military but also its commercial navy and was in urgent need to

19 For further details, see Karl-Heinrich Hansmeyer, "Grundsteuer", Handwörterbuch der Finanzwissenschaft, Stuttgart: Fischer, Tübingen: Mohr, Göttingen: Vandenhoeck and Ruprecht (3), 1981 (2), pp. 726-743 and V.G. Peterson, "Germany", in: Harry Gunnison Brown, Harold S. Buttenheim, Philip H. Cornick, Glenn E. Hoover (eds.) Land Value Taxation Around the World, New York: Schalkenbach. Harcourt Brace and Howe, 1920. 
attract capital for building shipping capacity. A system was therefore designed and perfected after World War II which creates commercial credit through the income tax code.

Take the problem of creating shipping capacity as an example and suggest a personal income tax rate for the relevant income categories of fifty percent. From this income can be deducted business losses. Assume an income of one million subject to the fifty percent rate. This creates capital in the amount of five hundred thousand marks if the income tax need not be paid.

Obviously, business losses can be taken off the income to be declared, which therefore results in the need to create a loss in the amount of one million mark, for which five hundred thousand marks are at the disposal of the business enterprise. Let us now collect investments from high income clients for the purpose of building the shipping capacity in question, an enterprise that certainly during its first year cannot yield a sizable profit but must yield a certain loss. However, the loss can be increased if the shipping capacity we are in the process of creating can be depreciated rapidly. Let us assume the prudent tax avoiding investor puts one hundred thousand mark into the ship building scheme. He thereby reduces his disposable income by one hundred thousand marks, but his taxable income remains at one million under the fifty percent tax rate. But let us assume he receives a loss statement relating to this one hundred thousand mark share of two hundred thousand marks in the first year. That means, his tax debt has been decreased by the same amount he actually invested, which means that he would be indifferent at that point. If the tax rate were not fifty percent but higher, a lower amount of real purchasing power and appropriately lower loss assignments would be needed in order to 
render him indifferent between investing money into tax avoiding schemes or handing it right over to the tax collector.

What has been dubbed a "scheme", of course, needs to be approved by the tax authorities. By approving these constructions, the tax authorities essentially assign away taxes owed to very specific projects which the government cannot itself conceivably undertake. And, indeed, German shipping capacity in the early twenties rose miraculously through this procedure.

In 1945, Germany had not only lost its navy, both military and commercial, but rather it had lost essentially everything and the country lay in ruins. What industrial capacity there was still remained subject to demountation, that is the dis-assembling of industrial plants and removal of productive capacity. These demountation actually continued well into the early fifties, after the establishment of the Federal Republic of Germany, in Western Germany in 1949 and the currency reform of 1948. The allied occupying powers had also insisted on a stiff progressive income tax rate of $90 \%$. Such an income tax rate, of course, stifles efforts at earning income, and therefore stifles efforts at leading the country through reconstruction into economic prosperity. By insisting, however, on such a stiff income tax rate, the allied powers had created ample opportunities for the scheme just described. Not only commercial ship building capacity had to be created, millions of homeless people who had either lost their homes through the bombing raids or had arrived in Western Germany as refugees, needed living space. Hence, provisions were entered into the tax code allowing for special deductions for ship building, the creation of residential rental housing and many others, these being the amendments to article seven of the income tax code, creating special opportunities for deducting losses from commercial activities. These losses in an accounting sense could, of course, be shown to have occurred, because long term investments had been made, where the investment comes first and 
the yield will appear over a long period of time. By allowing these deductions and, in addition accelerated depreciations, the fruits from these investments were made tax free, and the wealth created through the investments would also remain tax free if only the scheme of investing in preferred investment areas as detailed by the amendments to article seven of the income tax code would continue indefinetely. By allowing high income earners, however, to invest in crucial areas, German economic recovery received a strong impulse in two ways. High income earners faced a zero income tax (in the relevant tax brackets) if only they were willing to re-invest their income in those preferred investment areas, such as housing, real estate development, shipping and various others. And these indicated commercial areas received an almost unlimited supply of credit, a supply of credit only limited by the income earning capacity of the high income earners.

If we look at this phenomenon from the point of view of Henry George's distinction between land rents and improvements, we notice that indeed the improvements, even in the area of real estate development, remained tax free. Henry George's theory is, however, not only about improvements remaining tax free. It is about a tax constitution that balances government's revenues with a governement's ability to create rents of natural resources, and it is about economic development. We notice, that these two elements, in addition are remarkably present in the provisions of the German income tax code (amendments to article seven) as described here. Indeed, the income tax code was taken to become an engine of economic development, the credit for which development was created by taxes otherwise not collected. These tax deductions should, indeed, not be seen as tax expenditures, rather they were investments in the tax base. The creation of residential housing, for instance, involves multiple transactions which are all subject to the value added (or formerly sales) tax, and this tax indeed 
has proven to be a most fertile revenue source. They are also subject to the very fertile wage tax, as well. Yet, many of these transactions would never have taken place if the specific incentive structure embodied in the amendments to the tax code had not been conceived.

IV.

After the collapse of the German Democratic Republic, the reconstitution of the five new states and their accession according to article 23 of the German Basic Law to the Federal Republic of Germany, Germany faced the daunting task of reconstructing a landscape that had over the last decades been subject to massive dis-investment. Again, recourse was taken to the same scheme just outlined. This is also the reason why income tax legislation is exempt from European Union harmonization. The German income tax system due to its "Georgist" elements is so unique and dis-similar to other systems, that it is not possible to enter it into a process of harmonization before the reconstruction of Eastern Germany has been completed. In order to show how this is done in practice, a document is here being reproduced which consists in a prospect or invitation to invest into a particular real estate development program in the city of Jena in the state of Thuringia. 
21 See Reginald Hansen, Die praktischen Konsequenzen des Methodenstreits: eine Aufarbeitung der Einkommensbesteuerung, Berlin: Duncker \& Humblot, 1996, p. 
547. Many other examples can be found in the appendix to this book, which describes in great detail the intellectual foundations and practical realizations of the German income tax code. 
The original document, of course is in German, but it need not be translated here with the exception of the most sailiant features. The purpose of the investment is described as creating a service center with office and shop space in Jena. The manager of the enterprise is described as being Dr. Lothar Späth, a former Prime Minister of the State of Baden Württemberg known for his inventive use of tax and other incentives to lure major investments into that booming state. The total loss assignments are given by year, the first year yielding $144.55 \%$ the last year still some $9.73 \%$, the total being $234.15 \%$. Given a tax rate of $53 \%$, this investment still yields an after tax return of $18.87 \%$. But after five years, the share in this real estate project, by then no doubt developed and leased, can already be sold. As pointed out before, the profit from the sale can be tax exempt if it is being re-invested into a similar scheme.

\section{Conclusion}

This particular example shows, that the concept of land value taxation in Germany needs to be considered with respect to the most peculiar circumstances under which Germany has developed and the sometimes creative reactions to adverse constraints. The Georgist program involving the distinction between the rent of natural resources on the one hand and the improvements on the other, with the stipulation that the land rent could be taxed totally whereas the improvements should remain totally untaxed, this creating a tax constitution designed for economic development, where equity clearly takes second place behind economic efficiency, all these elements can be shown to exist to a certain extend in real estate taxation in Germany, but to a still larger and much more compelling extent in the interplay between the income tax code and corporate investment in specifically designated areas, such as, indeed, real estate 
development, but also other areas such as shipping or any specific area that might gain the priority of economic policy.

\section{List of References}

Jürgen Backhaus and J. J. Krabbe, "Henry George's Contribution to Modern Environmental Policy: Part One, Theoretical Postulates, "American Journal of Economics and Sociology, Vol. 50 (4), 1991 (pp. 485-501).

Jürgen Backhaus J. J. Krabbe, "Henry George's Contribution to Modern Environmental Policy: Part Two, An Application to Industrial Siting", The American Journal of Economics and Sociology, Vol. 51, January 1992, No. 1 (pp. 115-127).

Karl Bräuer, "Wertzuwachssteuer (Grundsstücksgewinnsteuer)", Handwörterbuch der Staatswissenschaften, Vol. 8, Jena: Gustav Fischer, 1928 (4), pp. 117-142.

Adolph Damaschke, Geschichte der Nationalökonomie, Jena: Fischer, 1909 (3), pp. 392-393.

Adolph Damaschke, Die Bodenreform, Jena: Fischer, 1916 (12), 1917 (14!).

Henry George, Progress and Poverty, San Francisco, 1979, New York: Appleton, 1880 (2)

Henry George, Fortschritt und Armut, translated by C.D.F. Gütschow, Berlin: Staude, 1882

Henry George, Fortschritt und Armut, translated by F. Dobbert, Halle: Hendel, no year [1891], in: Complete Domestic and International Library. 
Wilhelm Gerloff, "Die Wertzuwachssteuer in Literatur und Gesetzgebung”, Schmollers

Jahrbuch für Gesetzgebung, Verwaltung und Volkswirtschaft im deutschen Reiche, 37, 1913, pp. 1485-1497.

Reginald Hansen, Die praktischen Konsequenzen des Methodenstreits: eine Aufarbeitung der Einkommensbesteuerung, Berlin: Duncker \& Humblot, 1996.

Karl-Heinrich Hansmeyer, "Grundsteuer", Handwörterbuch der Finanzwissenschaft, Stuttgart: Fischer, Tübingen: Mohr, Göttingen: Vandenhoeck und Ruprecht (III), 1981 (2), pp. 726-743 John Maynard Keynes, The Economic Consequences of the Peace, New York: Harcourt Brace and Howe, 1920.

Friedrich List, Gutachten über die wirtschaftliche Reform des Königsreichs Ungarn 1845.

V.G. Peterson, "Germany", in: Harry Gunnison Brown, Harold S. Buttenheim, Philip H.

Cornick, Glenn E. Hoover (eds.) Land Value Taxation Around the World, New York: Schalkenbach.

Gustav Schmoller, "Henry George", in Gustav Schmoller, Zur Literaturgeschichte der Staatsund Sozialwissenschaften, Leipzig: Duncker \& Humblot, 1888, the original is dated 1882 and is a review of the Gütschow translation of 1882.

W. Schrameier, Aus Chiau Tchau's Verwaltung. Die Land-, Steuer-, und Zollpolitik des Chiau 


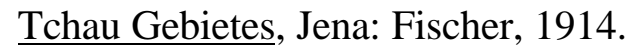

Joseph Alois Schumpeter, History of Economic Analysis, New York: Oxford University Press, 1954.

Fritz Stier-Somlo, "Grundsätzliches und Tatsächliches zu Wertzuwachssteuer", Jahrbücher für Nationalökonomie und Statistik, 1909, p. 1 ff. 